\title{
Analysis of the concept of Meaningful Learning in light of the Ausubel's Theory
}

\author{
Análise do conceito de Aprendizagem Significativa à luz da Teoria de Ausubel \\ Análisis del concepto de Aprendizaje Significativo bajo la luz de la Teoría de Ausubel
}

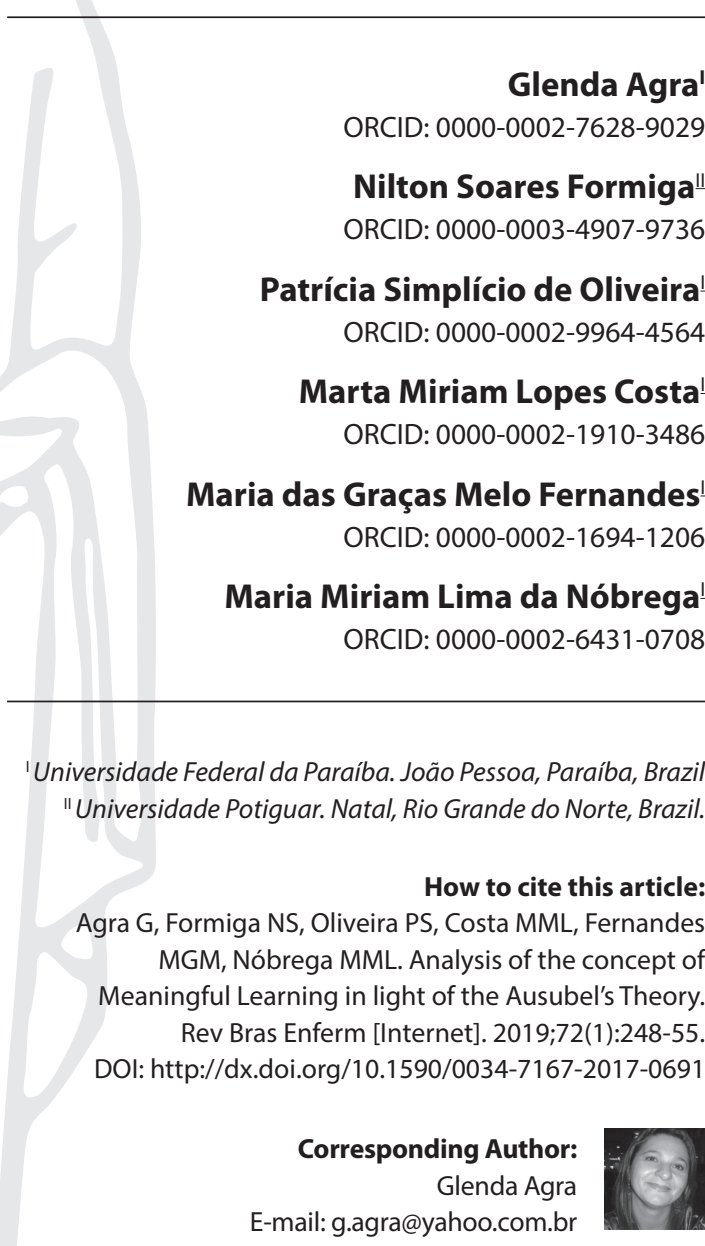

Submission: 08-16-2017

Approval: 07-04-2018

\begin{abstract}
Objective: To analyze the concept of Meaningful Learning, according to David Ausubel's Theory. Method: Integrative review using the Meleis's Theoretical Analysis model. Results: The following were identified as antecedents: Previous students' knowledge, potentially meaningful instructional material and student's willingness to learn. The attributes found were: Existence of previous knowledge that allows the connection with the new knowledge; interaction of previous and new knowledge in the cognitive structure; expansion of the cognitive structure through the incorporation of prior knowledge with the new. The consequent ones found: Existence of new knowledge in the cognitive structure of the student, that generate sense and meaning in the cognitive system of the student and that confers importance to him according to the utility for his daily life. Conclusion: The conceptual analysis carried out contributed to the establishment of a more complete definition for Meaningful Learning, which can be appreciated in teaching and research, regardless of the area of activity.
\end{abstract}

Descriptors: Concept Formation; Psychological Theory; Learning; Teaching; Nursing.

\section{RESUMO}

Objetivo: Analisar o conceito de Aprendizagem Significativa, conforme a Teoria de David Ausubel. Método: Revisão integrativa, utilizando o modelo de análise teórica de Meleis. Resultados: Foram identificados como antecedentes: Conhecimentos prévios dos alunos, material instrucional potencialmente significativo e disposição do aluno para aprender. Os atributos encontrados foram: Existência de conhecimentos prévios que possibilite a conexão com o novo conhecimento; interação de conhecimentos prévios e novos na estrutura cognitiva; ampliação da estrutura cognitiva por meio da incorporação do conhecimento prévio com o novo. Os consequentes encontrados: Existência de novos conhecimentos na estrutura cognitiva do aluno, que geram sentido e significado no sistema cognitivo do aluno e que lhe confere importância conforme a utilidade para sua vida cotidiana. Conclusão: $\mathrm{A}$ análise conceitual realizada contribuiu com a instituição de uma definição mais completa para a Aprendizagem Significativa, que poderá ser apreciada no ensino e na pesquisa, independentemente de área de atuação.

Descritores: Formação de Conceito; Teoria Psicológica; Aprendizagem; Ensino; Enfermagem.

\section{RESUMEN}

Objetivo: analizar el concepto de Aprendizaje Significativo, conforme a la Teoría de David Ausubel. Método: revisión integrativa, utilizando el modelo de análisis teórico de Meleis. Resultados: se identificaron como antecedentes: los conocimientos previos de los alumnos, el material instructivo potencialmente significativo y la disposición del alumno para aprender. Los atributos encontrados fueron: la existencia de conocimientos previos que posibiliten la conexión con el nuevo conocimiento; la interacción de conocimientos previos y nuevos en la estructura cognitiva; la ampliación de la estructura cognitiva por medio de la incorporación del conocimiento previo con lo nuevo. Los consecuentes encontrados fueron: la existencia de nuevos conocimientos en la estructura cognitiva del alumno, que generan sentido y significado en el sistema cognitivo del alumno y que le confiere importancia según la utilidad para su vida cotidiana. Conclusión: el análisis conceptual realizado contribuyó con la institución de una definición más completa para el Aprendizaje Significativo, que podrá ser apreciada en la enseñanza y en la investigación, independientemente del área de actuación.

Descriptores: Formación de Concepto; Teoría Psicológica; Aprendizaje; Enseñanza; Enfermería. 


\section{INTRODUCTION}

In general, a teaching situation corresponds to the moment when one person intentionally helps another to learn something. However, individual knowledge is not a concrete and directly observable object, but above all a set of mental representations constructed from the interpretative dynamics that the subject of knowledge establishes with the objects of the perceiving world $^{(1-2)}$. Thus, the act of teaching and learning is mediated by different representations of the same knowledge: the teacher's, the student's and the teaching material ${ }^{(1)}$.

Thus, learning in this dynamic corresponds to a process - continuous (because it is progressive), personal (by its idiosyncratic nature), intentional (it is up to the student to relate substantively the new information with the relevant ideas existing in their cognitive structure) , active (because it requires mental activity), dynamic, recursive (non-linear), interaction (between information and prior knowledge) and interactive (because it establishes relationships between subjects) - which generates a product always provisional characterized by a particular knowledge produced in a given moment and context $\mathrm{t}^{(2-3)}$.

In this perspective, a Meaningful Learning, according to David Ausubel ${ }^{(4)}$, author of the Meaningful Learning Theory (MLT), is a promising strategy in a formal teaching situation, which consists of non-arbitrary and non-literal interaction of new knowledge with relevant prior knowledge (subsumption). Thus, from successive interactions, a given subsumption progressively acquires new meanings, becomes richer, more refined, more differentiated, and is capable of serving as an anchor for new meaningful learning ${ }^{(4-5)}$. The central point of reflection in Ausubel's Theory ${ }^{(4)}$ is that of all the factors that influence learning, the most important is what the student previously knows; aspect considered starting point ${ }^{(4-6)}$.

In this sense, unraveling what the student already knows is more than identifying their representations, concepts and ideas, because it requires consideration of the totality of the cultural/ social being in their manifestations and bodily, affective and cognitive languages. For this, the teacher must be open so that the student can reveal their lived expectations, the objects incorporated in their life, the existential conditions and not only the intellectual aspect ${ }^{(2-6)}$.

The current teaching-learning process has collaborated for a mechanical learning, in which students are accustomed to memorize concepts, thereby overshadowing thinking. Mechanically learned knowledge is only applicable to situations that are already known and do not imply understanding, since they do not equip the student to act with autonomy in face of their reality ${ }^{(2)}$.

To plan, develop and evaluate a teaching, in the traditional and behavioral view of learning, which is known to be inadequate for the present, is as difficult as in the cognitive conception, but the overcoming of this misunderstanding lies in the individual and collective reflection on the knowledge that guides the current educational practice ${ }^{(2)}$. It is for this reason that MLT is the conceptual basis of this study.

The interest in studying this concept in the light of Ausubel's Theory ${ }^{(4)}$ arises through its relevance to teaching and research in Nursing, as well as to other areas of knowledge/science. Thus, investigating the concept of MLT within this theory contributes to an improvement of its understanding and applicability, so that its meaning expresses what occurs in the empirical reality ${ }^{(4,7-8)}$.

A concept is an idea or a mental construct elaborated on a phenomenon, being essential in the development of research, as well as in the construction of theories. The concepts comprise abstract attributes of reality and, consequently, represent more than words or mental images, since they do not capture the complex nature of concepts ${ }^{(9)}$.

In the last ten years, the researches in the area of teaching in Health point to the importance of the analysis of concepts, since this process is part of the construction of knowledge and can be a strategy to discover the delineation of the phenomenon. In order to do so, the results of the concept analysis process are useful for judging available measurement instruments as to the capacity to cover the phenomenon in question, the construction of measurement instruments, and also to allow the observation and critique of other interested parties in the same concept ${ }^{(9)}$.

\section{OBJECTIVE}

This study aims to analyze the concept of Meaningful Learning, delimiting its antecedents, attributes and consequents, according to Ausubel's Theory, with emphasis in the area of Nursing.

\section{METHOD}

For the operationalization of this phase of the Meleis'Theory analysis model, the integrative literature review method ${ }^{(10)}$ was used on the analysis of the concept of Meaningful Learning, proposed by Ausubel's Theory ${ }^{(4)}$. The model ${ }^{(11)}$ used as a method encompasses description, analysis, critique, test and support. The description can be made by elucidating its structural and functional components of the Theory. Analysis is defined as a process of identifying parts and components. Criticism is an examination or estimation of a situation. The theoretical test refers to an evaluation for the usefulness of the theory. Already the support test verifies validation alternatives, in congruence with the nature of the discipline.

Considering the aspects proposed by this model ${ }^{(11)}$, we used the concept analysis stage, which is divided into four units of analysis: Definitions, which are subdivided into semantics, logic and context; antecedents; consequences and examples. For the analysis of the term Meaningful Learning, among the mentioned analysis units of the concept, in the present study they opted for the definition, which gathers identification and description of different dimensions and components of the concept, antecedents and consequents.

In the conduction of the integrative review, the following steps were followed: Identification of the theme and selection of the hypothesis or research question; establishment of criteria for inclusion and exclusion of studies; sampling or searching in the literature; definition of the information to be extracted from the selected studies and categorization of the studies; evaluation of studies included in the integrative review; interpretation of results; and presentation of review or synthesis of knowledge ${ }^{(10)}$.

In the first stage, we tried to answer the guiding questions: What is the definition of Meaningful Learning? How is it characterized? What 
are the attributes that make up Meaningful Learning? What are the antecedents and consequents that make up Meaningful Learning?

The literature review was carried out over the internet from May to July 2016. The following inclusion criteria were established: Scientific studies available electronically in the databases or in the periodicals made available by the Portals of the Coordination for the Improvement of Higher Education Personnel (CAPES - Coordenação de Aperfeiçoamento de Pessoal de Nível Superior) and Virtual Health Library, intervention articles that address the theme or aspects of Meaningful Learning Theory, within all areas of Nursing interest, in the English, Portuguese or Spanish languages, in the time space from 2005 to 2015. As criteria exclusion criteria were considered: Repeated publications in databases, scientific studies not available in full, and articles that did not allude to Meaningful Learning or David Ausubel's Theory.

In order to search for the studies, the following databases were used: International Literature in Health Sciences (MEDLINE), Latin American and Caribbean Center for Health Sciences Information (LILACS), Brazilian Nursing Database (BDENF - Base de Dados de Enfermagem), Scientific Library Online (SciELO) and Cumulative Index to Nursing and Allied Health Literature (CINAHL) with the following terms: "Enfermagem", "Aprendizagem Significativa", "Ensino"; "Nursing", "Meaningful learning", "Teaching"; "Enfermería”, "Aprendizaje Significativo",'Enseñanza".

The crossings were performed with keywords with the Boolean operator AND, as follows: "Enfermagem"AND"Aprendizagem Significativa" AND "Ensino"; "Nursing" AND "Meaningful learning" AND "Teaching"; "Enfermería" AND" aprendizaje significativo" AND"enseñanza".

Initially, it was evaluated the title, abstract and descriptors that addressed the phenomenon "Meaningful Learning", according to the number of publications described in the databases: MEDLINE, SciELO, LILACS, BDENF (37 in English, 15 in Portuguese and 02 in Spanish) and CINAHL (30 in English). This stage includes a process of organization and reorganization of essential ideas and information collected in the literature, which become important to guide the researcher on how to define and measure each fundamental characteristic in the composition of the phenomenon. After a floating reading of these articles, it was observed that 12 were repeated, 24 were review studies and 15 did not allude to Meaningful Learning or David Ausubel's Theory, leaving 33 articles. After this stage, we proceeded to read in full these articles, and we could see that 23 did not allude to Meaningful Learning or to David Ausubel's Theory. In this sense, 10 articles were part of the sample, seven written in the Portuguese language and three in English.

The material was read independently by the researchers. The discussion phase of the main results found in the articles occurred through successive analyzes and reflections on their contributions to the construction of the teaching-learning process in Nursing, based on the Meaningful Learning Theory.

The information extracted from each of the articles were: Journal title, database, year of publication, title of article, objective, allusion to Meaningful Learning Theory or David Ausubel, teaching strategies and mode of application of Theory. Subsequently, we focused on the extraction of the essential characteristics: Theoretical and operational definitions, attributes, antecedents and consequents about the phenomenon "Meaningful Learning", considering the method of concept analysis. The essential characteristics, including attributes, antecedents and consequents were analyzed for cohesion and coherence, formalizing the information collected.

\section{RESULTS}

The sample consisted of ten articles published in national and international journals between 2005 and 2015.

The concept analysis ${ }^{(12)}$ made it possible to identify and describe the definitions of the concept of Meaningful Learning, according to the Meaningful Learning Theory ${ }^{(4)}$, in the area of Nursing. The following are the definitions, attributes, antecedents and consequents.

\section{Attributes}

For the identification of the essential attributes of the MLT concept, the following questions were used: How do authors define the concept? What characteristics or attributes do they indicate? What idea do the authors discuss about MLT?

The answers to these questions allowed the identification of the following attributes of the concept of Meaningful Learning: (a) Expansion of the cognitive structure through the incorporation of new ideas that relate to the preexisting ideas; (b) Existence of structured knowledge [...] that enables the connection with the new knowledge [...] and connects knowledge with the one it intends to absorb; (c) New information acquires meaning in the cognitive structure [...] interaction between a new knowledge and the previous one; (d) Interaction of a new material with what already exists in the cognitive structure; (e) Model [...] that expands knowledge through the assimilation of new concepts with the pre-existing ones [...] which serves as a basis for incorporating, understanding and fixing new knowledge in the cognitive structure the apprentice; (f) New information [...] generates sense and meaning [...] in relevant aspects of the cognitive structure.

In Chart 1, we highlight the definitions of Meaningful Learning with the referred authors of the studies of this review, attributes and conceptions of origin of teaching-learning.

Chart 1 - Definitions and Conceptions of Meaningful Learning Concept, João Pessoa, Paraíba, Brazil, 2016

\begin{tabular}{|l|l|l|}
\hline $\begin{array}{l}\text { Authors, Publication } \\
\text { Year and Journal }\end{array}$ & \multicolumn{1}{|c|}{ Definition of Meaningful Learning } & Conceptions \\
\hline $\begin{array}{l}\text { Mendoza et al., 2012 } \\
\begin{array}{l}\text { Mendoza et al., } \\
2012^{(14) .} \\
\text { Reusp }\end{array}\end{array}$ & $\begin{array}{l}\text { Expansion of cognitive structure by incorporating new ideas that relate to preexisting ideas in a non- } \\
\text { arbitrary and substantive way (a). Non-arbitrary means logical relation of new ideas to existing ones. } \\
\text { Substantive is the apprentice's ability to explain what happened to their own words. }\end{array}$ & Behavioral \\
\hline
\end{tabular}

To be continued 


\begin{tabular}{|c|c|c|}
\hline $\begin{array}{l}\text { Authors, Publication } \\
\text { Year and Journal }\end{array}$ & Definition of Meaningful Learning & Conceptions \\
\hline $\begin{array}{l}\text { Kalinowski et al., } \\
2012^{(15)} \text {. } \\
\text { Interface }\end{array}$ & $\begin{array}{l}\text { Meaningful Learning can be defined as the provision of a new knowledge structured in a logical way; the } \\
\text { existence of knowledge in the cognitive structure that enables the connection with the new knowledge, as well } \\
\text { as the explicit attitude of apprehending and connecting knowledge with the one that it intends to absorb. }\end{array}$ & Behavioral \\
\hline $\begin{array}{l}\text { Prado et al.,2011 }{ }^{(16)} \text {. } \\
\text { Rev Bras Enferm }\end{array}$ & $\begin{array}{l}\text { It is considered that learning is meaningful when new information acquires meaning for the student by } \\
\text { anchoring it in relevant aspects of its preexisting cognitive structure. It is characterized by the interaction } \\
\text { between the new knowledge and the previous one (c). }\end{array}$ & \multirow{3}{*}{ Social } \\
\hline $\begin{array}{l}\text { Kinchin; Hay, } 2005^{(17)} \text {. J } \\
\text { Adv Nurs }\end{array}$ & $\begin{array}{l}\text { Meaningful Learning is when the interaction of a new material occurs with what already exists in the } \\
\text { student's cognitive structure (d). }\end{array}$ & \\
\hline $\begin{array}{l}\text { Silva et al.,2013 } 3^{(18)} \text {. } \\
\text { Reusp }\end{array}$ & $\begin{array}{l}\text { Meaningful Learning is a mechanism that facilitates the acquisition and storage of new information as long as } \\
\text { existing knowledge in the student's cognitive structure acts as a kind of anchoring of the new knowledge (d). }\end{array}$ & \\
\hline $\begin{array}{l}\text { Carvalho et al., } 2015^{(19)} \text {. } \\
\text { Rev Enferm UFSM }\end{array}$ & $\begin{array}{l}\text { Meaningful Learning is a learning model in which the student expands his knowledge through the assimilation } \\
\text { of new concepts with the preexisting ones; This is done by means of an anchorage system, in which the } \\
\text { previous information anchors itself to the new information and thus expands its cognitive structure. The } \\
\text { main characteristics of Meaningful Learning are non-arbitrariness, which is understood by a logical and } \\
\text { relevant relationship between the new idea and the existing ones, which serves as a basis for incorporating, } \\
\text { understanding and fixing new knowledge in the cognitive structure of the learner (e); and substantive, which } \\
\text { ensures that once learned content, the student will be able to express the essence of the new information with } \\
\text { his own words, that is, it generates sense and meaning in the cognitive structure of the learner (f). }\end{array}$ & $\begin{array}{c}\text { Socio- } \\
\text { humanistic }\end{array}$ \\
\hline
\end{tabular}

\section{Antecedents and Consequents}

The analyzed studies brought as antecedents of Meaningful Learning: Previous knowledge, previous organizers, potentially meaningful material and student's willingness to learn. In general, the consequences of this use involve the acquisition of new meanings in the student's cognitive structure, in an interactive, organized and hierarchical way, with personal components in the cognitive system; attribution of meanings to a certain knowledge by the subject, according to the usefulness for their daily life and retention of knowledge, with possible oblivion, however, with ease of rescue and relearning. In order to improve the visibility and understanding of the reader, the following is described in Chart 2 the antecedents and consequents of the concept of Meaningful Learning, according to Ausubel's Theory ${ }^{(4)}$.

Chart 2 - Antecedents and Consequents of the Concept of Meaningful Learning, João Pessoa, Paraíba, Brazil, 2016

\begin{tabular}{|c|c|c|c|}
\hline Antecedents & Sources & Consequents & Sources \\
\hline $\begin{array}{l}\text { Previous } \\
\text { knowledges }\end{array}$ & 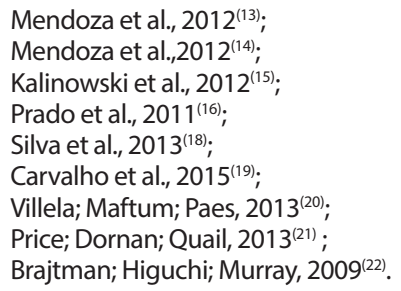 & $\begin{array}{l}\text { Acquisition of new meanings in the cognitive structure, in } \\
\text { an interactive, hierarchical and organized way, with personal } \\
\text { components present in the cognitive system of each subject. }\end{array}$ & 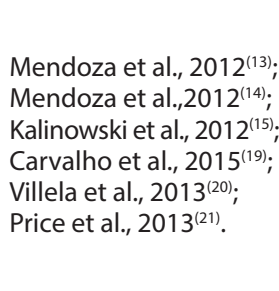 \\
\hline $\begin{array}{l}\text { Previous } \\
\text { organizers }\end{array}$ & Silva et al., $2013^{(18)}$ & $\begin{array}{l}\text { Meaning that the learner attributes to a given knowledge and gives it } \\
\text { importance according to the utility for his daily life. }\end{array}$ & Kalinowski et al., 2012 ${ }^{(15)}$. \\
\hline $\begin{array}{l}\text { Potentially } \\
\text { meaningful } \\
\text { material }\end{array}$ & 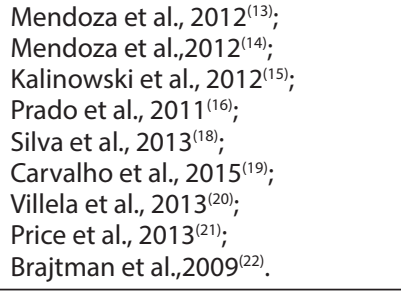 & \multirow{2}{*}{$\begin{array}{l}\text { It presents retention of knowledge; however there may be } \\
\text { forgetfulness, which is easily rescued when the learner re- } \\
\text { studies the content. }\end{array}$} & \multirow{2}{*}{$\begin{array}{l}\text { Carvalho et al., 2015 (19); } \\
\text { Villela et al., } 2013^{(20)} \text {; } \\
\text { Price et al., } 2013^{(21)} \text {. }\end{array}$} \\
\hline $\begin{array}{l}\text { The learner must } \\
\text { show willingness } \\
\text { to learn }\end{array}$ & 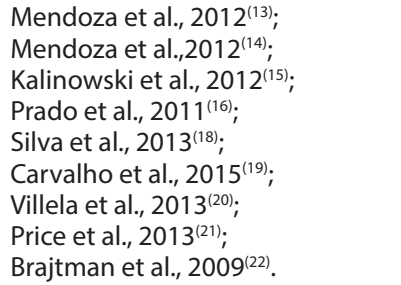 & & \\
\hline
\end{tabular}




\section{DISCUSSION}

The conceptual analysis evidenced different approaches to the concept of Meaningful Learning, based on the area of knowledge in which it is used, permeating behaviorist, social, cognitive and socio-humanistic conceptions.

The definition of Meaningful Learning, which focuses on the behavioral conception, is supported by the teacher's oral explanations, which conveys ideas (as encouragement) to the students, so that they are translated as archivers of knowledge, and in turn demands that students to use their mental activity, reinforced by the teacher, with the purpose of accumulating, storing and reproducing the information coming from the presented ideas.

In this field of instruction of the teaching organization, the student has a passive cognitive function, being seen as a reservoir of information that will later be useful for life. In addition to using techniques that highlight new information and correct expositions, the teacher must also provide direct and immediate reinforcement, in order to produce students' behavioral changes and their stability. The role of the teacher, who is central to his scientific knowledge, overlaps with the student's role. The latter, instead of actively learning, only accumulates knowledge that must be able to 'faithfully' repeat ${ }^{(23-24)}$.

In the behavioral perspective of learning, the passivity, criticality and reproducibility of the student's information impede the development of creativity and although individual rhythms are respected, intrinsic curiosity and motivation are not emphasized as a sine qua non condition for the advancement of the knowledge of a subject matter ${ }^{(25)}$. The student will likely become apathetic as they depend on the teacher for their cognitive and behavioral growth in learning, thus not having a concern in teaching the student to think. The teaching emphasizes the know-how or the acquisition and maintenance of the answers ${ }^{(23-24,26)}$.

Regarding the definition of Meaningful Learning with an emphasis on Social Learning Theory, it maps a perspective on learning that includes consideration of the learner's personal characteristics, patterns of behavior and the environment ${ }^{(26-28)}$. This, in turn, worries that learning takes place in the context of a social situation and suggests that a meaningful part of what the learner learns results from the student-environment interaction with a modeling in their active-learning learning. With this, the role of the teacher or the action of a subject can easily lead to a modeling of students' learning.

In this context, learning is an information processing activity, allowing environmental behaviors and events to be transformed into symbolic representations that serve as guidelines of action. If in a behaviorist perspective, behavior must be reinforced with a view to its acquisition and maintenance, in modeling learning, even when reinforced, learning presupposes previous observation experience. However, incentives can influence the student, determining which behaviors should be observed ${ }^{(23,26,28)}$.

The true emphasis of the student as constructor of his own knowledge arises with the cognitive-constructivist theories of learning, which produce a determinant character to the students' previous conceptions. In this context, the definition of Meaningful Learning in cognitive conception establishes a preoccupation with learning to think and learning to learn, not with obtaining observable behavior; in addition to making the student responsible for his personal learning process and helping him to be cognitively and affectively persistent ${ }^{(4)}$. In this perspective, the cognitive learning process presents two relatively independent dimensions: a) how the knowledge to be learned is available to the student; and b) the way students incorporate this information into their existing cognitive structures. In this sense, discussions promoted in the classroom draw the attention away from the teacher to a more effective evaluation, aiming to regulate the teaching-learning process and implying the student in the construction of his knowledge. The active role of the student appears to claim autonomy in the act of knowing and the central role given to discovery and exploration are considered as decisive in learning ${ }^{(4-6,23,25-29)}$.

Spontaneity, the importance of empathic feelings and emotions, the right of people to make their own choices, and creativity are the basis of the humanist approach to learning, which was addressed in the last definition of Meaningful Learning. However, it is worth noting that in addressing the "freedom" condition proposed by this learning perspective, political-pedagogical and didactic issues cannot be disregarded, since the condition of being free of the student in the learning process in humanism does not exclude the compliance with the teaching plan and academic schedules. What may be spontaneous and free is the internal dynamics of the student's study, in which the student will be able to find new concepts, techniques and academic behaviors that contribute to the qualitative and quantitative advance of his knowledge about a certain theme ${ }^{(25,28-30)}$.

It is noteworthy that Ausubel ${ }^{(4)}$ defines the concept of Meaningful Learning as a process of acquisition of new knowledge, from which it conceives the meaning as a result of this process ${ }^{(4-6,26,28-29,31)}$. For Ausubel ${ }^{(4)}$, meaning is a'phenomenological' product of the learning process, in which the potential meaning, inherent in symbols, becomes cognitive content, differentiated for a given individual ${ }^{(32)}$.

Based on the reflections expressed herein, a dissonance between the conceptions of Meaningful Learning presented in the area of Nursing was observed, since each article explored only part of the concept of Meaningful Learning proposed by Ausubel's Theory ${ }^{(4)}$. Thus, this incompleteness of the concept deserves attention, since it reinforces the superficial and polysemic appropriation of the concept of Meaningful Learning, limiting, therefore, the theoretical and applied understanding of Meaningful Learning in the area of study ${ }^{(1,4,6,33)}$. Thus, in some circumstances, there is a risk of considering learning to be meaningful in relation to teaching methodologies, an inadmissible situation, since to be considered a Meaningful Learning, it needs to appropriate an underlying theory or philosophy.

With respect to the antecedents of the concept of Meaningful Learning in Chart 2, situations, events or phenomena that precede the concept of interest are observed. Antecedents helps in understanding the social context in which the concept is generally used, as well as favoring its refinement ${ }^{(12)}$. In the present study, antecedents were identified through the answers to the question: How is the concept described (roles, skills and context)?

The first antecedent of the concept of Meaningful Learning is the prior knowledge or subsumption or anchor idea, defined as specific and relevant knowledge that the student presents in his cognitive structure and whose function is to enable new meanings to the knowledge that is being presented or discovered by the same ${ }^{(4)}$. It is emphasized that the attribution of meanings to 
the new knowledge learned depends on the existence of subsumptions in the student's cognitive structure. In this sense, it is worth mentioning that Ausubel ${ }^{(4)}$ mentions cognitive structure, as the total and organized content of ideas of the subject ${ }^{(1,6,32-33)}$.

The previous organizer ${ }^{(4)}$ is an instructional modality with characteristics of a higher level of abstraction, generality and inclusivity in relation to the learning material, whose purpose is to help the subject to perceive the relation between the new knowledge and the subsumptions existing in his cognitive structures, which serve to facilitate learning, since they assume the function of 'cognitive bridges'(1,6,32-33).

In regard to potentially meaningful, non-arbitrary and substantive material ${ }^{(4)}$, it is necessary to first understand that the term non-arbitrary or logically meaningful or has logical meaning constitutes non-randomness, meaning that the interaction of meanings is not with any previous idea, but with some specific and relevant knowledge existing in the student's cognitive structure; and the substantive or non-literal term means 'no', literally. Thus, the material must have a relation between the cognitive structure and the previous knowledge of the subject and that is situated within the domain of the human intellectual capacity ${ }^{(1,6,32-33)}$.

In this sense, it is pertinent to distinguish logical from psychological ${ }^{(4)}$; the first depends exclusively on the 'nature of the material', since the emphasis of meaning lies in the relation between material and ideas, and corresponds to the domain of human intellectual capacity; the second, refers to an idiosyncratic experience of the subject, that is, that the availability of content is relevant and adequate in the student's cognitive structure ${ }^{(1,6,32-33)}$.

Finally, in order for learning to be meaningful, the learner must want to relate the new knowledge in a non-arbitrary (logical) and substantive (non-literal) way to their previous knowledge ${ }^{(4)}$. This does not mean that the student is motivated or has a preference for the subject studied; it means that the student is predisposed to relate the new knowledge with the previous knowledge, leaving them more elaborate, more enriched, more stable; In the same way, new knowledge acquires meaning and is integrated into the cognitive structure ${ }^{(1,4,6,32-33)}$.

One can observe the consequences of the concept of Meaningful Learning. These refer to events or situations resulting from their use ${ }^{(12)}$. For the identification of the consequences, the following question was used: What is meant to achieve with Meaningful Learning?

The result of Meaningful Learning is the acquisition of new meanings in the cognitive structure, in an interactive, hierarchical and organized way, with personal components present in the cognitive system of each student, which is conceptualized as a process of interaction between previous and new knowledge, in which new information acquires meaning and is integrated into the cognitive structure of the subject and prior knowledge becomes more stable, more elaborate and with greater capacity to anchor other new knowledge ${ }^{(4)}$. It is worth mentioning that, in this interactive process, both knowledge (the new and the previous) $)^{(1,4,6,32-33)}$.

When learning is meaningful, new meanings are hierarchical, since some subsumptions are more general and inclusive than others, in addition to being organized, because the student presents in their cognitive structure relevant and specific aspects for learning new information ${ }^{(1,4,6,32-33)}$.
Another consequence of Meaningful Learning relates to the meaning that the student attributes to a particular knowledge and gives it importance according to the usefulness for his / her daily life, that is, when the student learns meaningfully, it presents the ability to transfer meanings to new situations, differently from what happens in mechanical learning, in which the student is able to deal only with known and routine situations, since little or no previous information is found in the student's cognitive structure ${ }^{(1,4,6,32-33)}$.

By referring to forgetfulness as a consequence of Meaningful Learning, Ausubel ${ }^{(4)}$ points out that Meaningful Learning is not one in which the subject never forgets. The student presents knowledge retention, however, there may be forgetfulness, which is easily rescued when the student re-studies the content. According to Ausubel ${ }^{(4)}$, forgetfulness is a natural continuity of Meaningful Learning, but the student does not completely forget what he has learned. It is a progressive loss of the dissociability of the new knowledge in relation to the knowledge that gave it meaning and served as a cognitive anchorage; not a loss of meanings s $^{(1,4,6,32-33)}$.

In Meaningful Learning ${ }^{(4)}$, forgetfulness is residual, this is because forgotten knowledge is inserted in the subsumption and for this reason there are some advantages, for example: The acquired knowledge is retained and remembered for longer, the student increases its capacity to learn other content more easily and even if the original information has been forgotten, it is easy to relearn ${ }^{(1,4,6,32-33)}$.

Based on the identified results, where gaps in the use of the concept of Meaningful Learning were identified, the conceptual analysis carried out assumed a singular importance, since the present study proposes as a result a definition for Meaningful Learning and, according to Ausubel's Theory ${ }^{(4)}$, suggests a broad and consistent definition, and can be used in different areas of knowledge.

Given the above, Meaningful Learning is a teaching-learning process, in which the student as a biopsychosocial being and participant in this process, is motivated to learn, thus, understands, reflects and attributes new concepts, starting from previous knowledge and experiences, modifying the existing meanings, by means of the organization and integration in the cognitive structure of the previous and new concepts, making them meaningful, which, necessarily, are transferred to other situations that experience.

\section{Study limitations}

From this analysis, the discrete use of David Ausubel's Meaningful Learning Theory by Nursing in Brazil, limitations of the analysis of the concept of Meaningful Learning in national and international studies made available in the world data network was evidenced as limitations, which may reflect in an incomplete state-of-the-art characterization of the concept; in some studies, it was observed the absence of descriptions of antecedents and consequent indispensable to the use of the concept of Meaningful Learning, making difficult its application and the conjunction of the complete concept.

Considering the findings, it is necessary to carry out research with the use of Meaningful Learning Theory and presentation of their respective results, conceptual analyzes, as well as studies that synthesize the existing productions about conceptual analysis of Meaningful Learning or another unit of critical analysis, since the present bibliographical research was restricted to the analysis 
of the concept, attributes, antecedents and consequents of the Meaningful Learning Theory in the light of David Ausubel.

\section{Contributions to the sectors of Nursing, Health or Public Policy}

Understanding the concept of Meaningful Learning facilitates its use by researchers, teachers and care nurses and supports their actions within the teaching-learning process. This makes possible the full application of the concept, including by Nursing teachers, who have long adopted in their classes, although empirically or unconsciously.

\section{CONCLUSION}

The term'Meaningful Learning' has been used in many studies that address Health Education, including in Nursing. However, most of these do not emphasize David Ausubel's Theory as it is often used to designate that the learning process is important. In this sense, analyzing the concept of Meaningful Learning made it possible to extend the understanding of both the concept and its applicability through the definition of its attributes, antecedents and consequents, and it is possible to clarify its meaning.

During the analysis of the concept of Meaningful Learning, different attributes were identified in the definitions of Meaningful Learning, used by the authors of the studies, which led to the retrieval of different conceptions of the teaching-learning process, thus revealing that Nursing still presents, in the educational environment, paradigms of traditional teaching, but that has been gradually modifying and assigning new meanings in the way of thinking, acting and educating in the teacher-student dynamics in the learning process.

Thus, it was observed that Nursing, as a science of care, has been using theories in order to raise the quality of teaching, research and consequent care provided; works of this nature contribute to the dissemination of new knowledge, often still unknown to teachers and researchers and by students in the process of their academic and scientific training in the area of Health and Human Care.

\section{REFERENCES}

1. Moreira MA. [After all, what is meaningful learning?] Rev Qurriculum [Internet]. 2012 Mar [cited 2016 Aug 20]; 25: 29-56. Available from: http://www.if.ufrgs.br/ moreira/alfinal.pdf Spanish.

2. Lemos ES. [The meaningful learning theory and its relationship with teaching and research on teaching]. Rev Aprendizagem Significativa [Internet]. 2011 [cited 2016 Aug 20];1(3):47-52. Available from: http://www.if.ufrgs.br/asr/artigos/Artigo_ID17/v1_n3_a2011.pdf Portuguese.

3. Lamburú CE, Barros MA, Silva OHM. [Multimodal and multiple representation, significant learning and subjectivity: three reconcilable scientific education frameworks]. Ciên Educ [Internet]. 2011 [cited 2016 Aug 20];17(2): 469-87. Available from: http://dx.doi.org/10.1590/ S1516-73132011000200014 Portuguese.

4. Ausubel, DP. The psychology of meaningful verbal learning. New York: Grune \& Stratton; 1963.255 p.

5. Moreira MA. Ensenanza de la física: aprendizaje significativo, aprendizaje mecânico y criticidade. Rev Ensenanza de la Física [Internet]. 2014 [cited 2016 Aug 15];26(1): 45-52. Available from: http://www.revistas.unc.edu.ar/index.php/revistaEF/article/viewFile/9515/10290

6. Moreira MA. La Teoría del Aprendizaje Significativo Crítico: un referente para organizar la enseñanza contemporânea. Rev Iberoam Educac Mat [Internet]. 2012 [cited 2016 Aug 16];31(5):9-20. Available from: http://www.fisem.org/www/union/revistas/2012/31/archivo_5_de_ volumen_31.pdf

7. Bousso RS, Poles K, Cruz DALM. Nursing concepts and theories. Rev Esc Enferm USP [Internet]. 2014 [cited 2016 Aug 20 ]; 48 (1):144-8. Available from: http://dx.doi.org/10.1590/S0080-623420140000100018

8. Waltz CF, Strickland OL, Lenz ER. Measurement in nursing research. 3 nd ed. Philadelphia: Davis; 2010.539 p.

9. Fontenele FC, Pagliuca LMF, Cardoso MVLML. Skin care of the newborn: concept analysis. Esc Anna Nery [Internet]. 2012 [cited 2016 Aug 20]; 16(3):480-5. Available from: http://eean.edu.br/detalhe_artigo.asp?id=778

10. Mendes KDS, Silveira RCCP, Galvão CM. [Integrative literature review: a research method to incorporate evidence in health care and nursing.] Texto Contexto Enferm [Internet]. 2008 [cited 2016 Aug 20];17(4):758-64. Available from: http://dx.doi.org/10.1590/S010407072008000400018 Portuguese.

11. Meleis Al. Theoretical nursing: development and progress. 5 th ed. Philadelphia (PA): Lippincont William e Wilkins; 2012.688 p.

12. Tofthagen R, Fagerstrøm LM. Rodgers' evolutionary concept analysis--a valid method for developing knowledge in nursing science. Scand J Caring Sci. 2010; 24 Suppl 1:21-31. doi: 10.1111/j.1471-6712.2010.00845.x

13. Mendoza IYQ, Peniche ACG, Püschel VAA. Knowledge of hypothermia in nursing professionals of surgical center. Rev Esc Enferm USP [Internet]. 2012 [cited 2016 Aug 16]; 46(Esp):123-9. Available from: http://dx.doi.org/10.1590/S0080-62342012000700018

14. Mendoza IYQ, Peniche ACG. Educational intervention regarding hypothermia: a teaching strategy for education in the Surgery Department. Rev Esc Enferm USP [Internet]. 2012 [cited 2016 Aug 18];46(4):849-55. Available from: http://dx.doi.org/10.1590/S0080-62342012000400010

15. Kalinowski CE, Massoquetti RMD, Peres AM, Larocca LM, Cunha ICKO, Gonçalves LS et al. [Participative methods in teaching administration within nursing]. Interface Comunicação Saúde Educação [Internet]. 2013 [cited 2016 Aug 18]; 17(47):959-67. Available from: http://dx.doi. org/10.1590/S1414-32832013005000029 Portuguese. 
16. Prado C, Vaz DR, Almeida DM. [Theory of significant learning: development and evaluation of virtual classroom in Moodle platform]. Rev Bras Enferm [Internet]. 2011 [cited 2016 Aug 20]; 64(6):1114-21. Available from: http://dx.doi.org/10.1590/ S0034-71672011000600019 Portuguese.

17. Kinchin I, Hay D. Using concept maps to optimize the composition of collaborative student groups: a pilot study. J Adv Nurs [Internet]. 2005 [cited 2016 Aug 20];51(2):182-7. Available from: https://doi.org/10.1111/j.1365-2648.2005.03478.x

18. Silva CC, Oliveira AKS, Egry EY, Lima Neto EA, Anjos UU, Silva ATMC. Constructing a Gowin's V diagram to analyze academic work in Nursing. Rev Esc Enferm USP [Internet]. 2013 [cited 2016 Aug 16]; 47(3):702-6. Available from: doi: 10.1590/S0080-623420130000300026

19. Carvalho DPSRP, Rego ALC, Ferreira KS, Sila SB, Vitor AF, Ferreira Júnior MAF. [Meaningful learning theory as a proposal for innovation in nursing education: student experience]. Rev Enferm UFSM. [Internet]. 2015 [cited 2016 Aug 20]; 5(1):186-92. Available from: doi: 10.5902/2179769213210 Portuguese.

20. Villela JC, Maftum MA, Paes MR. [The teaching of mental health a nursing undergraduate course: a case study]. Texto Contexto Enferm [Internet]. 2013 [cited 2016 Aug 20]; 22(2):397-406. Available from: http://dx.doi.org/10.1590/S0104-07072013000200016 Portuguese.

21. Price J, Dornan J, Quail L. Seeing is believing - Reducing misconceptions about children's hospice care through effective teaching with undergraduate nursing students. Nurs Educ Pract [Internet]. 2013 [cited 2016 Aug 20]; 13 (5):361-5. Available from: doi: 10.1016/j. nepr.2012.09.013

22. Brajtman S, Higuchi K, Murray MA. Developing meaningful learning experiences in palliative care nursing education. Int J Palliat Nurs. 2009;15(7):327-31. doi: 10.12968/ijpn.2009.15.7.43422

23. Festas MIF. [Contextualized learning: foundations pedagogical and practices]. Educ Pesq [Internet]. 2015 [cited 2016 Aug 20];41(3):713-28. Available from: http://dx.doi.org/10.1590/S1517-9702201507128518 Portuguese.

24. Peres CM, Vieira MNC, Altafim ERP, Mello MB, Suen KS. [Pedagogical approaches and their relationship with the learning theories]. Medicina (Ribeirão Preto) [Internet]. 2014 [cited 2016 Aug 16]; 47(3):249-55. Available from: http://revista.fmrp.usp.br/2014/vol47n3/1_Abordagenspedagogicas-e-sua-relacao-com-as-teorias-de-aprendizagem.pdf Portuguese.

25. Fonseca DM. [Bachelard's scientific pedagogy: a reflection in favor of the quality of teacher practice and research]. Educação e Pesquisa [Internet]. 2008 [cited 2016 Aug 20];34(2):361-70. Available from: http://dx.doi.org/10.1590/S1517-97022008000200010 Portuguese.

26. Guista AS. Concepções de aprendizagem e práticas pedagógicas. Educ Rev [Internet]. 2013 [cited 2016 Aug 20]; 29(1):20-36, 2013. Available from: doi: 10.1590/S0102-46982013000100003

27. Bastable SB. O enfermeiro como educador: princípios de ensino-aprendizagem para a prática de enfermagem. Porto Alegre: Artmed; 2010. $688 \mathrm{p}$.

28. Job SCPD. Teorias da aprendizagem: uma revisão da literatura. Id on line Rev Psicol [Internet]. 2011 [cited 2016 Aug 14];5(15):22-30. Available from: http://idonline.emnuvens.com.br/id/article/view/18/18

29. Sousa ATO, Formiga NS, Oliveira SHS, Costa MML, Soares MJGO. [Using the theory of meaning learning in nursing Education]. Rev Bras Enferm [Internet]. 2015 [cited 2016 Aug 20]; 68(4):713-22. Available from: . doi: http://dx.doi.org/10.1590/0034-7167.2015680420 Portuguese

30. Escario S. Concepção humanista (Carl Rogers) como recurso de atuação na educação para o trânsito - aprendizagem contextualizada. Rev Bras Educ [Internet]. 2014 [cited 2016 Aug 15]; 2(3): 83-95. Available from: http://periodicos.pucminas.br/index.php/ arquivobrasileiroeducacao/article/view/P.2318-7344.2014v2n3p83/8004

31. Pantoja GCF, Moreira MA, Herscovitz VE. [The teaching of fundamental quantum mechanics concepts to undergraduate physics students]. Rev Electrónica Investigación en Educación en Ciencias [Internet]. 2014 [cited 2016 Aug 20]; 9(1): 22-39. Available from: http://www.scielo. org.ar/pdf/reiec/v9n1/v9n1a02.pdf Spanish

32. Moreira MA, Masini EFS. Aprendizagem significativa: a Teoria de David Ausubel. São Paulo: Centauro; 2008. 112 p.

33. Moreira MA. Teorias de aprendizagem. 2 ed. São Paulo: EPU; 2014. 248 p. 